\title{
The Effects of Metformin, Ethinyl Estradiol/Cyproterone Acetate, and Metformin Ethinyl Estradiol/Cyproterone Acetate Combination Therapy on Carotid Artery Intima-media Thickness in Patients with Polycystic Ovary Syndrome
}

\author{
Polikistik Over Sendromlu Olgularda Metformin, Etinil Estradiol/Siproteron Asetat ve \\ Metformin-etinil Estradiol/Siproteron Asetat Kombinasyonu Tedavisinin Karotis Arter \\ İntima Media Kalınlığı Üzerine Etkileri
}

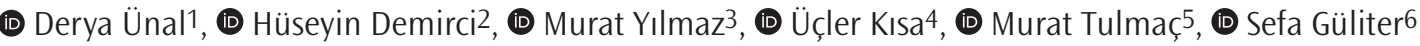 \\ 1Yedikule Chest Diseases and Thoracic Surgery Training and Research Hospital, Clinic of Immunology and Allergy Diseases, İstanbul, Turkey \\ ${ }^{2}$ Medicana International Ankara Hospital, Clinic of Endocrinology and Metabolic Diseases, Ankara, Turkey \\ ${ }^{3}$ Kırıkkale University Faculty of Medicine, Department of Endocrinology and Metabolic Diseases, Kırıkkale, Turkey \\ ${ }^{4}$ Kırıkkale University Faculty of Medicine, Department of Biochemistry, Kırıkkale, Turkey \\ ${ }^{5}$ Kırıkkale University Faculty of Medicine, Department of Cardiology, Kırıkkale, Turkey \\ ${ }^{6}$ Kırıkkale University Faculty of Medicine, Department of Gastroenterology, Kırıkkale, Turkey
}

\begin{abstract}
Introduction: Patients with polycystic ovary syndrome (PCOS) are in the risk group for early-onset cardiovascular disease. There are few studies evaluating physiological and inflammatory cardiovascular risk factors in PCOS. Our study aimed to measure carotid intima-media thickness (IMT) in PCOS cases and to assess the effects of metformin, ethinyl estradiol/cyproterone acetate (EE/CA) and metformin + EE/ CA combination therapy on carotid IMT, insulin resistance, C-reactive protein (CRP), apelin and adiponectin.
\end{abstract}

Methods: Basal carotid IMT, insulin resistance [Homeostasis model assessment insulin resistance (HOMA-IR)], apelin, adiponectin, and CRP values were evaluated in 60 women with PCOS and 43 healthy volunteers between the ages of 18 and 45 . After baseline evaluation, patients were divided into metformin $(n=20), E E / C A(n=20)$ and metformin $+E E / C A(n=20)$ treatment groups. Treatment regimens were administered for six months. At the end of the treatment, the same parameters were reevaluated.

Results: Compared with the control group, CRP ( $p=0.003)$, HOMA-IR $(p=0.004)$ and IMT $(p=0.049)$ were significantly higher, and adiponectin $(p=0.002)$ and apelin $(p=0.031)$ levels were significantly lower in patients with PCOS. At the end of the six-month treatment, the adiponectin level in the metformin $(p=0.012)$ and metformin $+E E / C A$ groups $(p=0.012)$, and the apelin level in the metformin $(p=0.024), E E / C A(p=0.024)$ and metformin $+E E / C A$ groups $(p=0.024)$ were significantly higher. There was no statistically significant change in CRP level in all

\section{öZ}

Amaç: Polikistik over sendromu (PKOS) erken dönemde ortaya çıkan kardiyovasküler hastalık için risk grubundadır. PKOS'de, fizyolojik ve enflamatuvar kardiyovasküler risk faktörlerini değerlendiren az sayıda çalışma vardır. Çalışmamızın amacı, PKOS olgularında karotis intima media kalınlığını (IMK) ve ayrica metformin, etinil estradiol/siproteron asetat (EE/SA) ve metformin + EE/SA kombinasyon tedavisinin karotis IMK, insülin direnci, C-reaktif protein (CRP), apelin ve adiponektin üzerine etkilerini değerlendirmektir.

Yöntemler: Çalıșmamıza katılan 18-45 yaş arasındaki 60 PKOS'li kadında ve 43 sağıklı gönüllü kadında bazal karotis IMK, insülin direnci [Homeostasis model assessment insulin resistance (HOMA-IR)], apelin, adiponektin ve CRP değerlendirmeleri yapıldı. Bazal değerlendirmeden sonra, hastalar metformin $(n=20), E E / S A(n=20)$ ve metformin + EE/SA $(n=20)$ tedavi gruplarına ayrıldı. Tedavi rejimleri 6 ay boyunca uygulandı. Tedavi sonunda aynı parametreler tekrar değerlendirildi.

Bulgular: Kontrol grubuyla karșılaştıııldı̆̆ında PKOS'li olguların CRP $(p=0,003)$, HOMA-IR $(p=0,004)$, IMK $(p=0,049)$ değerleri istatistiksel olarak anlamlı derecede daha yüksek, adiponektin $(p=0,002)$, apelin $(p=0,031)$ düzeyleri kontrol grubundan istatistiksel olarak daha düşük saptandı. Altı aylık tedavinin sonunda adiponektin seviyesi metformin $(p=0,012)$ ve metformin + EE/SA grubunda $(p=0,012)$, apelin seviyesi ise metformin grubu $(p=0,024)$, $E E / S A$ grubu $(p=0,024)$, ve metformin + EE/SA grubunda $(p=0,024)$ anlamlı olarak yüksek saptandı. Üç tedavi grubunda da CRP seviyesinde istatistiksel olarak anlamlı değișim yoktu $(p>0,05)$. Üç tedavi grubunda
Address for Correspondence/Yazışma Adresi: Derya Ünal MD, Yedikule Chest Diseases and Thoracic Surgery Training and Research Hospital, Clinic of Immunology and Allergy Diseases, İstanbul, Turkey

Phone: +90 2124090200 E-mail: derya_erdogdu@hotmail.com ORCID ID: orcid.org/0000-0001-9741-5939

Cite this article as/Atıf: Ünal D, Demirci H, Yılmaz M, Kısa Ü, Tulmaç M, Güliter S. The Effects of Metformin, Ethinyl Estradiol/Cyproterone Acetate, and Metformin Ethinyl Estradiol/Cyproterone Acetate Combination Therapy on Carotid Artery Intima-media Thickness in Patients with Polycystic Ovary Syndrome. İstanbul Med J 2020; 21(1): 47-52.

(c) Copyright 2020 by the istanbul Training and Research Hospital/istanbul Medical Journal published by Galenos Publishing House.

(C) Telif Hakkı 2020 istanbul Ĕgitim ve Araștırma Hastanesi/istanbul Tıp Dergisi, Galenos Yayınevi tarafından basıımıștır.
Received/Geliș Tarihi: 27.12.2019 Accepted/Kabul Tarihi: 08.01.2020 
treatment groups $(p>0.05)$. There was no statistically significant change in carotid IMT value in all treatment groups $(p>0.05)$.

Conclusion: According to these results, we can say that women with PCOS have subclinical atherosclerosis and that metformin treatment has a positive effect on subclinical atherosclerosis.

Keywords: Polycystic ovary syndrome, carotid artery intimamedia thickness, insulin resistance, apelin, adiponectin, C-reactive protein da karotis IMK değerinde istatistiksel olarak anlamlı değișim yoktu $(p>0,05)$.

Sonuç: Bu sonuçlara göre PKOS'de subklinik aterosklerozun varlığını ve metformin tedavisinin subklinik ateroskleroz üzerine olumlu etki gösterdiğini söyleyebiliriz.

Anahtar Kelimeler: Polikistik over sendromu, karotis arter intima media kalınlığı, insülin direnci, apelin, adiponektin, C-reaktif protein

\section{Introduction}

Polycystic ovary syndrome (PCOS) is the most common endocrinological disorder (5-10\%) in women of reproductive age (1). It was first described by Stein and Leventhal (2) in 1935. The diagnosis of the disease, the symptoms of which spread over a broad spectrum, was based on clinical signs and symptoms and biochemical markers, and today there is no consensus on diagnostic criteria (3).

First, in 1990, the National Institutes of Health Consensus Conference specified the diagnostic criteria for PCOS as the exclusion of other causes of hyperandrogenism, characterized by menstrual irregularity, increased androgen level, and adrenal hyperplasia. Insulin resistance, increased luteinizing hormone/follicle-stimulating hormone ratio, and ultrasonographic symptoms have been identified as possible criteria (4).

In 2003, the European Society for Human Reproduction and Embryology and the American Society for Reproductive Medicine convened in Rotterdam, Netherlands, to rearrange the diagnostic criteria for the diagnosis of PCOS. Since PCOS is a syndrome, it was decided after this meeting that a single criterion was not sufficient for clinical diagnosis and that at least two of the following criteria should be present after the exclusion of androgen excess and other medical causes causing menstrual irregularity:

\section{Oligo/anovulation,}

2. Clinical or biochemical hyperandrogenemia findings,

3. PCOS appearance in at least one ovary on ultrasound (US) (defined as more than 12 2-9 mm, follicles in the ovary or ovarian volume more than $10 \mathrm{~mL}$ ) and exclusion of other diseases (5).

In 2009, the diagnostic criteria of PCOS were reorganized by the Androgen Excess Society.

\section{Androgen Excess Society Criteria}

1. Hyperandrogenism: Hirsutism and/or hyperandrogenemia,

2. Ovarian dysfunction: Oligo-anovulation and/or polycystic ovaries,

3. Exclusion of other hyperandrogenemia-causing conditions (such as late-onset congenital adrenal hyperplasia, androgen-secreting tumors, Cushing's syndrome, thyroid dysfunction, and hyperprolactinemia) (6).

PCOS progresses with clinical symptoms such as dysfunctional bleeding, infertility, hirsutism, and acne. The most common of these is menstrual irregularity due to anovulation (7). Also, there are women with regular menstrual cycles despite high androgen levels (8). In PCOS, hyperandrogenism is evaluated with clinical (hirsutism, acne, androgenic alopecia) and biochemical (increase in serum total and free testosterone levels) findings (6). There is an $80 \%$ PCOS with hyperandrogenemia. Ovaries are enlarged (volume $>10 \mathrm{~mL}$ ), and polycystic ovaries (12 or more follicles with a size of $2-9 \mathrm{~mm}$ ), can be detected. It is sufficient to see them in a single ovary (9).

Many patients with PCOS have insulin resistance independent of body mass index. The risk of developing type 2 diabetes mellitus (DM) in patients with PCOS has been found to increase 2-5 times (10). Also, the frequency of metabolic syndrome is higher in patients with PCOS than in the normal population. The risk of cardiovascular disease (CVD) increases in patients with DM and metabolic syndrome (11).

Adiponectin is a newly defined adipocytokine expressed in adipocytes. Adiponectin is effective in insulin resistance and in preventing the development of type $2 \mathrm{DM}$. It plays a vital role in vascular endothelial dysfunction and the pathogenesis of atherosclerosis. In clinical studies, adiponectin has been shown to have a protective effect from atherosclerosis. Serum adiponectin level is low in women with type 2 DM, obesity, and insulin resistance. In studies with PCOS, plasma adiponectin level was also found to be low (12).

Apelin has been shown to have an expression in the central nervous system, lung, adipose tissue, heart, and breast. Apelin is thought to play a role in the regulation of insulin and glucose levels (13).

Many studies have revealed that those with increased C-reactive protein (CRP) levels have a much higher risk of CVD, including stroke, sudden death, and peripheral vascular disease $(14,15)$. The majority of the studies in PCOS have been shown to increase the level of CRP (15).

Carotid intima-media thickness (IMT) measurement is one of the methods that detect the atherosclerotic process in the asymptomatic period and is also a technique showing endothelial dysfunction and early atherosclerotic changes. Studies investigating the subclinical CVD in PCOS by detecting the presence of coronary artery calcification and carotid IMT were performed.

A significant correlation was observed between carotid IMT and testosterone, and androgens were thought to play an essential role in the development of atherosclerosis. It is predicted that atherogenic potential is increased in patients with PCOS in relation to androgen excess, regardless of obesity (16).

Treatment goals in PCOS can be listed as correction of hyperandrogenism, menstrual dysfunction, and providing fertility. Oral contraceptive agents 
(OCS), long-acting GnRH analogs, and insulin sensitivity-enhancing agents can be used in androgen-reducing therapy. After understanding that insulin resistance has a significant effect on the development of PCOS in recent years, agents that increase insulin sensitivity have taken their place in the treatment options (17). Insulin sensitivity increasing drugs such as metformin and glitazones have started to be used intensively in the treatment of PCOS (17).

In this study, we aimed to determine whether the carotid IMT, homeostatic model assessment of insulin resistance (HOMA-IR), apelin, adiponectin and CRP levels in PCOS cases differ from the control group, and to evaluate how these parameters respond to three different treatment approaches, including Metformin, Ethinyl estradiol/cyproterone acetate $(\mathrm{EE} / \mathrm{CA})$ and metformin $+\mathrm{EE} / \mathrm{CA}$.

\section{Methods}

\section{Ethics Committee Approval and Project Support}

Written approval was obtained for the study from Kırıkkale University Faculty of Medicine Local Ethics Committee on 03.06.2009 with the number of 2009/089.

\section{Selection of the Study Cohort}

A total of 60 patients diagnosed with PCOS in accordance with the criteria of Rotterdam 2003, aged between 18 and 45, who applied to the Kırıkkale University Faculty of Medicine Department of Endocrinology and Metabolic Diseases, and 43 age-matched, healthy volunteers were included in our study (5). The patients were randomized to the treatment group according to their order of admission.

Twenty patients received $2 \times 1 \mathrm{~g}$ /day metformin, 20 patients received $0.035 \mathrm{mg}$ EE / $2 \mathrm{mg}$ CA / d 1 1 1 (between $5^{\text {th }}-25^{\text {th }}$ day of menstruation, 21 days) and 20 patients received 2x1 g/g metformin + EE/CA (between $5^{\text {th }}-25^{\text {th }}$ day of menstruation, 21 days) combined therapy. Baseline examinations were repeated at the $6^{\text {th }}$ month of treatment. These procedures were performed only once in the control group.

Before starting the study, all patients in the PCOS and control groups were informed about the study, and patient consent was obtained. Patients with coronary artery disease, congestive heart failure, late-onset congenital adrenal hyperplasia, Cushing's syndrome, hypothyroidism, hyperthyroidism, type 2 DM, androgen-secreting ovarian or adrenal tumors, and patients receiving antiandrogen treatment and treatment affecting insulin sensitivity were also not included in the study.

\section{Anthropometric Measurements, Collection of Samples, Laboratory Analysis Methods and Vascular Evaluations}

In all cases included in the study, fasting blood glucose and fasting serum insulin levels were measured after at least 10 hours of fasting. HOMAIR was calculated using the formula fasting blood glucose $(\mathrm{mmol} / \mathrm{L}) \mathrm{x}$ fasting insulin $(\mu \mathrm{U} / \mathrm{L}) / 22.5$ (18).

CRP was evaluated with the turbidometric method. Serum adiponectin (Human Adiponectin AssayPro ELISA; Biotech Inst Spect) and apelin (Human Apelin Biotech in ELx Autostrip Washer) levels were measured collectively.
The menstrual statuses of the patients were evaluated according to the 6 month menstrual cycles before the study. Menstrual patterns were defined as "regular" (21-35 days), "irregular" (35-180 days), "polymenorrhea" (21 days or less), "oligomenorrhea" (35-180 days) and "amenorrhea" (longer than 180 days) (3). Pelvic US evaluations of all cases were performed on the $3^{\text {rd }}-5^{\text {th }}$ days of the menstrual cycle.

For the carotid artery IMT measurement, patients were positioned in the supine position with their heads tilted backward. Measurements were made in the right and left carotid arteries by determining a $1 \mathrm{~cm}$ segment within the first $2 \mathrm{~cm}$ distal region from the common carotid artery bulb using the General Electric Vivid S5 ultrasonography device and $12 \mathrm{~L}$ Doppler ultrasonography probe. Based on the far-edge measurement method of the US device, the maximum and mean carotid IMT values of the segment under consideration were determined. The measurement was performed for both common carotid arteries.

\section{Statistical Analysis}

All data obtained from the study were analyzed using SPSS 17.0. All data were expressed as mean \pm standard deviation (SD). After conducting descriptive statistical analyses (frequency, percentage distribution, mean $\pm S D$ ), the suitability of variables to normal distribution was evaluated with the Kolmogorov-Smirnov test. Initially, the difference between treatment groups was tested with one-way ANOVA. The levels of biochemical, inflammatory, and carbohydrate metabolism parameters of the groups before and after the treatment were analyzed with the Wilcoxon signed-rank test. $\mathrm{P}<0.05$ values were considered statistically significant.

\section{Results}

Sixty PCOS patients and 43 volunteers were included in the study. There were 20 patients receiving metformin treatment, 20 patients receiving EE/CA treatment, and 20 patients receiving metformin $+\mathrm{EE} /$ CA combination therapy in the PCOS treatment group. Among patients receiving metformin treatment, treatment was discontinued due to B12 deficiency in two patients and severe gastrointestinal complaints in one patient. In one patient receiving EE/CA treatment, treatment was discontinued due to elevated liver enzymes. Also, four patients from the Metformin group, nine patients from the EE/CA group and five patients from the metformin + EE/CA combination group were excluded from the study because they did not come to the $6^{\text {th }}$ month controls and they were not included in the statistical evaluation. The total number of patients who came for control in the $6^{\text {th }}$ month of treatment was 38 (63.3\%). The number of patients who completed the study was 13 in the metformin group, 10 in the EE/CA group, and 15 in the metformin + EE/ CA combination group.

\section{Comparison of the Pre-treatment Parameters of Individuals in the PCOS and Control Groups}

Compared with the control group, CRP $(p=0.003)$, HOMA-IR $(p=0.004)$ and carotid IMT $(p=0.049)$ values of PCOS cases were found to be significantly higher. Adiponectin $(p=0.002)$ and apelin $(p=0.031)$ levels of PCOS cases were significantly lower than the control group (Table 1). 


\section{Comparison of Pre-treatment Parameters of Three Treatment Groups}

A statistically significant difference was found between the levels of apelin $(p=0.040)$, adiponectin $(p=0.007)$ and $\operatorname{CRP}(p=0.019)$ in the three treatment groups. There was no statistically significant difference between the carotid IMT and HOMA-IR levels of the three groups ( $p>0.05$ ) (Table 2).

\section{Comparison of Parameters of Three Treatment Groups Measured at Six Months of Treatment}

There was a statistically significant difference between IMT $(p=0.018)$, adiponectin $(p=0.010)$ and CRP $(p=0.019)$ levels at the $6^{\text {th }}$ month of treatment of the three treatment groups (Table 3). The significant difference between IMT values was found to be due to the mean value of the metformin group being higher than the mean value of the $E E /$ CA group ( $p=0.046$, respectively). It was found that the significant difference between adiponectin levels was due to the mean level of the metformin group being lower than the mean level of the EE/CA group $(p=0.033)$. It was found that the significant difference between CRP levels was due to the mean level of the metformin group being higher than the mean level of the metformin $+E E / C A$ group $(p=0.002)$. There was no statistically significant difference between HOMA-IR and apelin levels of the three groups ( $p>0.05)$.

\section{Comparison of the Parameters Before and After Treatment in Treatment Groups}

Metformin treatment group: Significant decrease in HOMA-IR $(p=0.048)$ values and significant increase in apelin $(p=0.024)$ and adiponectin

\begin{tabular}{|c|c|c|c|}
\hline & $P \operatorname{COS}(n=60)$ & Control $(n=43)$ & p \\
\hline Adiponectin ( $\mu \mathrm{g} / \mathrm{mL})$ & $10.64 \pm 6.76$ & $14.61 \pm 5.80$ & 0.002 \\
\hline Apelin (ng/mL) & $2.63 \pm 2.89$ & $3.78 \pm 2.20$ & 0.031 \\
\hline Carotid IMT (mm) & $0.42 \pm 0.078$ & $0.39 \pm 0.06$ & 0.049 \\
\hline CRP (mg/dL) & $91.35 \pm 27.05$ & $81.79 \pm 28.27$ & 0.003 \\
\hline HOMA-IR & $3.01 \pm 1.78$ & $2.15 \pm 0.903$ & 0.004 \\
\hline
\end{tabular}

PCOS: polycystic ovary syndrome, IMT: intima media thickness, CRP: C-reactive protein, HOMA-IR: homeostatic model assessment of insulin resistance

Table 2. Comparison of pre-treatment values of laboratory parameters of the treatment group

Groups

\begin{tabular}{|c|c|c|c|c|}
\hline & $\begin{array}{l}\text { Metformin } \\
(n=13)\end{array}$ & $\begin{array}{l}\mathrm{EE} / \mathrm{CA} \\
(n=10)\end{array}$ & $\begin{array}{l}\text { Metformin + } \\
\text { EE/CA } \\
(n=15)\end{array}$ & $\mathbf{p}$ \\
\hline & Mean \pm SD & Mean \pm SD & Mean \pm SD & \\
\hline $\begin{array}{l}\text { Carotid IMT } \\
\text { (\% change) }\end{array}$ & $0.45 \pm 0.08$ & $0.40 \pm 0.09$ & $0.44 \pm 0.05$ & NS \\
\hline HOMA-IR & $3.60 \pm 1.89$ & $2.65 \pm 2.00$ & $2.91 \pm 1.55$ & NS \\
\hline Apelin (ng/mL) & $2.69 \pm 4.03$ & $3.45 \pm 3.49$ & $1.81 \pm 0.47$ & 0.040 \\
\hline $\begin{array}{l}\text { Adiponectin } \\
(\mu \mathrm{g} / \mathrm{mL})\end{array}$ & $6.37 \pm 2.63$ & $12.99 \pm 7.67$ & $9.00 \pm 5.97$ & 0.007 \\
\hline $\operatorname{CRP}(\mathrm{mg} / \mathrm{dL})$ & $8.94 \pm 9.21$ & $2.90 \pm 3.62$ & $1.87 \pm 1.39$ & 0.019 \\
\hline
\end{tabular}

$(p=0.012)$ levels were detected at the end of the $6^{\text {th }}$ month of treatment. There was no significant difference between IMT values and CRP levels before and after treatment ( $p>0.05)$ (Table 4).

$\mathrm{EE} / \mathrm{CA}$ treatment group: There was a significant increase in apelin levels $(p=0.024)$ after six months of treatment. There was no significant difference between the carotid IMT, HOMA-IR, adiponectin, and CRP levels of these cases before and after treatment $(p>0.05)$ (Table 5).

Metformin + EE/CA treatment group: There was a significant increase in apelin $(p=0.024)$ and adiponectin $(p=0.012)$ levels after 6 months of treatment. There was no significant difference between IMT, HOMA-IR, and CRP levels before and after treatment ( $p>0.05$ ) (Table 6).

\section{Discussion}

In patients with PCOS, carotid IMT has been evaluated in many studies. Talari et al. (19) found that the carotid artery IMT increased in patients with PCOS compared to the control group). In the study conducted by Talbott et al. (20), the increase in carotid IMT was shown among women over 45 years of age with PCOS compared to the control group, but not in women with PCOS in the 30-44 years age group. Similar to these studies, we found in our study that the carotid IMT value was higher in PCOS cases than the control group.

\section{Table 3. Comparison of parameters of three treatment groups} measured at six months of treatment

Groups

\begin{tabular}{|l|l|l|l|l|}
\hline IMT & $0.45 \pm 0.06 *$ & $0.39 \pm 0.05$ & $0.40 \pm 0.05$ & 0.018 \\
\hline HOMA-IR & $2.80 \pm 1.47$ & $2.63 \pm 2.58$ & $2.51 \pm 1.66$ & AD \\
\hline Apelin $(\mathrm{ng} / \mathrm{mL})$ & $3.59 \pm 2.24$ & $4.71 \pm 3.81$ & $4.18 \pm 1.88$ & AD \\
\hline Adiponectin $(\mu \mathrm{g} / \mathrm{mL})$ & $9.53 \pm 2.93 *$ & $14.91 \pm 7.73$ & $13.92 \pm 8.86$ & 0.010 \\
\hline CRP $(\mathrm{mg} / \mathrm{dL})$ & $6.73 \pm 6.92 * *$ & $3.30 \pm 2.83$ & $2.43 \pm 1.92$ & 0.019
\end{tabular}

*Significant difference between metformin and EE/CA groups $(p<005)$ **Significant difference between metformin and metformin + EE/CA groups $(p<005)$. IMT: intima media thickness, SD: standard deviation, CRP: C-reactive protein, HOMAIR: homeostatic model assessment of insulin resistance, EE/CA: ethinyl estradiol/ cyproterone acetate

Table 4. Comparison of pre-treatment and post-treatment levels of parameters in the group receiving metformin treatment

Metformin

\begin{tabular}{|l|l|l|l|}
\hline & $\begin{array}{l}\text { Pre-treatment } \\
(\mathbf{n = 1 3 )}\end{array}$ & $\begin{array}{l}\text { Post- } \\
\text { treatment } \\
(\mathbf{n = 1 3 )}\end{array}$ & $\mathbf{p}$ \\
\hline Mean \pm SD & Mean \pm SD & \\
\hline IMT (\% change) & $0.45 \pm 0.08$ & $0.45 \pm 0.06$ & NS \\
\hline HOMA-IR & $3.60 \pm 1.89$ & $2.80 \pm 1.47$ & 0.048 \\
\hline Apelin $(\mathrm{ng} / \mathrm{mL})$ & $2.69 \pm 4.03$ & $3.59 \pm 2.24$ & 0.024 \\
\hline Adiponectin $(\mu \mathrm{g} / \mathrm{mL})$ & $6.37 \pm 2.63$ & $9.53 \pm 2.93$ & 0.012 \\
\hline CRP $(\mathrm{mg} / \mathrm{dL})$ & $8.94 \pm 9.21$ & $6.73 \pm 6.92$ & NS \\
\hline
\end{tabular}

SD: standard deviation, IMT: intima media thickness, CRP: C-reactive protein, HOMA-IR: homeostatic model assessment of insulin resistance, NS: not significant 
In their study, Song et al. (21) found that PCOS cases had high insulin resistance. In our study, we found that HOMA-IR values in PCOS cases were higher than the control group.

The presence of a correlation between serum apelin levels and insulin resistance in PCOS is still controversial (22). Chang et al. (23) evaluated both obese and non-obese cases in their study and found that the level of apelin in PCOS patients was lower than the control group. We found lower levels of apelin in PCOS cases than the control group. To date, no study investigating the effect of metformin and EE/CA treatments on apelin in patients with PCOS has been conducted. On the other hand, there was a significant increase in serum apelin levels in all treatment groups (metformin, EE/CA, and metformin + EE/CA) in PCOS at the end of the $6^{\text {th }}$ month of treatment. We think that this result is vital since it is the first and significant result related to the subject in the literature.

Serum adiponectin levels in PCOS patients have been investigated in many studies. In the study conducted by Demirci et al. (24), plasma adiponectin level was found to be low in patients with PCOS. In our study, adiponectin level $(p=0.002)$ of patients with PCOS was found statistically lower than the control group.

The majority of the studies in PCOS have shown increased levels of CRP $(19,25)$. In a meta-analysis, it was found that increased CRP levels

\begin{tabular}{|c|c|c|c|}
\hline \multicolumn{4}{|l|}{$\mathrm{EE} / \mathrm{CA}$} \\
\hline & $\begin{array}{l}\text { Pre-treatment } \\
(n=10)\end{array}$ & $\begin{array}{l}\text { Post-treatment } \\
(n=10)\end{array}$ & \multirow{2}{*}{ p } \\
\hline & Mean \pm SD & Mean \pm SD & \\
\hline IMT (\% change) & $0.40 \pm 0.09$ & $0.39 \pm 0.05$ & NS \\
\hline HOMA-IR & $2.65 \pm 2.00$ & $3.63 \pm 3.58$ & NS \\
\hline Apelin (ng/mL) & $3.45 \pm 3.49$ & $4.72 \pm 3.81$ & 0.024 \\
\hline Adiponectin $(\mu \mathrm{g} / \mathrm{mL})$ & $12.99 \pm 7.67$ & $14.91 \pm 7.73$ & NS \\
\hline CRP (mg/dL) & $2.90 \pm 3.62$ & $3.30 \pm 2.83$ & NS \\
\hline
\end{tabular}

Table 6. Comparison of pre-treatment and post-treatment levels of parameters in the group receiving metformin + EE/CA treatment

Metformin + EE/CA

\begin{tabular}{|l|l|l|l|}
\hline & $\begin{array}{l}\text { Pre-treatment } \\
(\mathbf{n = 1 5 )}\end{array}$ & $\begin{array}{l}\text { Post-treatment } \\
(\mathbf{n}=15)\end{array}$ & $\mathbf{p}$ \\
\hline Mean \pm SD & Mean \pm SD & \\
\hline IMT (\% change) & $0.44 \pm 0.05$ & $0.40 \pm 0.05$ & NS \\
\hline HOMA-IR & $2.91 \pm 1.55$ & $2.51 \pm 1.66$ & NS \\
\hline Apelin $(\mathrm{ng} / \mathrm{mL})$ & $1.81 \pm 0.47$ & $4.18 \pm 1.88$ & 0.024 \\
\hline Adiponectin $(\mu \mathrm{g} / \mathrm{mL})$ & $9.00 \pm 5.97$ & $13.91 \pm 8.86$ & 0.012 \\
\hline CRP $(\mathrm{mg} / \mathrm{dL})$ & $1.87 \pm 1.39$ & $2.43 \pm 1.92$ & NS \\
\hline SD: Stand & & & \\
\hline
\end{tabular}

SD: standard deviation, IMT: intima media thickness, CRP: C-reactive protein, HOMA-IR: homeostatic model assessment of insulin resistance, EE/CA: ethinyl estradiol/cyproterone acetate, NS: not significant decreased in patients with PCOS after metformin treatment (25). In our study, we found that CRP level was significantly higher in patients with PCOS compared to the control group.

In a study by Sahin et al. (26), 20 women with PCOS were compared with 20 age-matched healthy women, and it was shown that six months of metformin $2550 \mathrm{mg} /$ day treatment did not cause a significant change in the carotid IMT value in women with PCOS. Similar to the study of Sahin et al. (26), we determined that six months of metformin 2000 $\mathrm{mg}$ /day treatment did not cause a significant change in the carotid IMT value. However, we found that six months of metformin $2000 \mathrm{mg} /$ day treatment decreased the HOMA-IR value and increased the levels of adiponectin and apelin.

A combination of OCS and metformin is a crucial treatment option in obese and non-obese PCOS patients. In a study conducted by Mitkov et al. (27), it was shown that combined EE/CA treatment with metformin did not impair insulin sensitivity. In our study, we found that six months of treatment with metformin and EE/CA did not change the HOMA-IR value. We found that while PCOS cases treated with metformin + EE/ CA did not change carotid IMT, HOMA-IR and CRP levels, apelin, and adiponectin levels increased significantly.

\section{Conclusion}

We detected increased carotid IMT in PCOS cases, which is an early symptom of atherosclerosis. However, in patients with PCOS, serum levels of adiponectin and apelin were low, and CRP levels were high. We did not find a significant decrease in carotid IMT in all three treatment groups after treatment. We found an increase in serum apelin levels in all three treatment groups, and we found that this is the first and significant result in the literature. While adiponectin level increased in metformin and metformin + EE/CA group, it did not change in the $\mathrm{EE} / \mathrm{CA}$ group. According to these results, we think that new, large-scale, prospective, and randomized studies are needed to evaluate subclinical and clinical atherosclerosis in PCOS cases.

Ethics Committee Approval: Written approval was obtained for the study from Kırıkkale University Faculty of Medicine Local Ethics Committee on 03.06.2009 with the number of 2009/089.

Informed Consent: Patient consent was obtained.

Peer-review: Externally peer-reviewed.

Author Contributions: Surgical and Medical Practices - D.Ü., M.Y., M.T.; Concept - D.Ü., M.Y., H.D., S.G.; Design - D.Ü., H.D., S.G., M.T.; Data Collection and/or Processing - D.Ü., M.Y., M.T., Ü.K.; Analysis and/or Interpretation - D.Ü., H.D., S.G.; Literature Search - D.Ü., M.Y., H.D., S.G.; Writing Manuscript - D.Ü., H.D., S.G.

Conflict of Interest: No conflict of interest was declared by the authors.

Financial Disclosure: The authors declared that this study received no financial support.

\section{References}

1. Bellver J, Rodríguez-Tabernero L, Robles A, Muñoz E, Martínez F, Landeras J, et al. Polycystic ovary syndrome throughout a woman's life. J Assist Reprod Genet 2018; 35: 25-39. 
2. Stein IF, Leventhal ML. Amenorrhea associated with bilateral polycystic ovaries. Am J Obstet Gynecol 1935; 29: 181-91.

3. Ricardo Aziz R. Controversy in clinical endocrinology: diagnosis of Polycystic Ovarian Syndrome: The Rotterdam Criteria Are Premature. J Clin Endocrinol Metab 2006; 91: 781-5.

4. Zawadzki JK, Dunaif A. 1992 Diagnostic criteria for polycystic ovary syndrome: towards a rational approach. In: Dunaif A, Givens JR, Haseltine FP, Merriam GR, eds. Polycystic ovary syndrome. Boston: Blackwell Scientific; 377-84.

5. Rotterdam ESHRE/ASRM-Sponsored PCOS consensus workshop group. Revised 2003 consensus on diagnostic criteria and long-term health risks related to polycystic ovary syndrome (PCOS). Hum Reprod 2004; 19: 41-7.

6. Azziz R, Carmina E, Dewailly D, et al. The Androgen Excess and PCOS Society criteria for the polycystic ovary syndrome: the complete task force report. Fertil Steril 2009;91:456-88

7. Ramezani Tehrani F, Amiri M. Polycystic Ovary Syndome in adolescents. Challenges in diagnosis and treatment. Int J Endocrinol Metab 2019; 17: e91554.

8. Hayes MG, Urbanek M, Ehrmann DA, Armstrong LL, Lee JY, Sisk R, et al. Genome-wide association of polycystic ovary syndrome implicates alterations in gonadotropin secretion in European ancestry populations. Nat Commun 2015; 6: 7502 .

9. Giampaolino P, Della Corte L, De Rosa N, Mercorio A, Bruzzese D, Bifulco G et al. Ovarian volume and PCOS: A controversial issue. Gynecol Endocrinol. 2018; 34: 229-32.

10. Jayasena CN, Franks S. The Management of patients with polycystic ovary syndrome. Nat Rev Endocrinol 2014; 10: 624-36.

11. Glintborg D, Rubin KH, Nybo M, Abrahamsen B, Andersen M. Cardiovascular disease in a nationwide population of Danish women with polycystic ovary syndrome. Cardiovasc Diabetol 2018; 17: 37.

12. Zahary MN, Harun NS, Yahaya R, Nik Him NAS, Rohin MAK, Ridzwan NH, et al. Serum adiponectin and resistin: Correlation with metabolic syndrome and its associated criteria among temiar subtribe in Malaysia. Diabetes Metab Syndr 2019; 13: 2015-9.

13. Gourdy P, Cazals L, Thalamas C, Sommet A, Calvas F, Galitzky M, et al. Apelin administration improves insulin sensitivity in overweight men during hyperinsulinaemic-euglycaemic clamp. Diabetes Obes Metab 2018; 20: 15764.

14. Blumenfeld Z. The possible practical implication of high CRP levels in PCOS. Clin Med Insights Reprod Health 2019; 22; 13.

15. Legro RS. Evaluation and treatment of polycystic ovary syndrome. In: De Groot, LJ, Chrousos, G, Dungan, K., eds. Endotext. South Dartmouth, MA: MDText.com, Inc.; 2017.
16. Teng HW, Chien YW, Hsu MI, Chen Cl. The relationship between carotid intimamedia thickness and endogenous androgens in young women with polycystic ovary syndrome in Taiwan. Gynecol Endocrinol 2013; 29: 238-41.

17. Al Khalifah RA, Florez ID, Dennis B, Thabane L, Bassilious E. Metformin or oral contraceptives for adolescents with polycystic ovarian syndrome: A metaanalysis. Pediatrics 2016; 137. pii: e20154089.

18. Yuan C, Liu X, Mao Y, Diao F, Cui Y, Liu J. Polycystic ovary syndrome patients with high BMI tend to have functional disorders of androgen excess: a prospective study. J Biomed Res 2016; 30: 197-202.

19. Talari HR, Poladchang S, Hamidian Y, Samimi M, Gilasi HR, Ebrahimi FA, et al. The Effects of Omega-3 and Vitamin E Co-supplementation on carotid intimamedia thickness and inflammatory factors in patients with polycystic ovary syndrome. Oman Med J 2018; 33: 473-9.

20. Talbott EO, Zborowski JV, Boudreaux MY, McHugh-Pemu KP, Sutton-Tyrrell K, Guzick DS. The relationship between C-reactive protein and carotid intimamedia wall thickness in middle-aged women with polycystic ovary syndrome. J Clin Endocrinol Metab 2004; 89: 6061-7.

21. Song DK, Hong YS, Sung YA, Lee $H$. Insulin resistance according to $\beta$-cell function in women with polycystic ovary syndrome and normal glucose tolerance. PLoS One 2017; 25: 12

22. Bongrani A, Mellouk N, Rame C, Cornuau M, Guérif F, Froment P, et al. Ovarian expression of adipokines in polycystic ovary syndrome: A role for chemerin, omentin, and apelin in follicular growth arrest and ovulatory dysfunction? Int J Mol Sci 2019; 20.

23. Chang CY, Tsai YC, Lee CH, Chan TF, Wang SH, Su JH. Lower serum apelin levels in women with polycystic ovary syndrome. Fertil Steril 2011; 95: 2520-3.e1-2.

24. Demirci H, Yilmaz M, Ergun MA, Yurtcu E, Bukan N, Ayvaz G. Frequency of adiponectin gene polymorphisms in polycystic ovary syndrome and the association with serum adiponectin, androgen levels, insulin resistance and clinical parameters. Gynecol Endocrinol 2010; 26: 348-55.

25. Wang J, Zhu L, Hu K, Tang Y, Zeng X, Liu J, et al. Effects of metformin treatment on serum levels of $C$-reactive protein and interleukin- 6 in women with polycystic ovary syndrome: A meta-analysis A PRISMA-compliant article. Medicine (Baltimore) 2017; 96

26. Sahin Y, Unluhizarci K, Yilmazsoy A, Yikilmaz A, Aygen E, Kelestimur F. The effects of metformin on metabolic and cardiovascular risk factors in nonobese women with polycystic ovary syndrome. Clin Endocrinol (Oxf) 2007; 67: 904-8.

27. Mitkov M, Pehlivanov B, Terzieva D. Combined use of metformin and ethinyl estradiol-cyproterone acetate in polycystic ovary syndrome. Eur J Obstet Gynecol Reprod Biol 2005; 118: 209-13. 